\title{
Indigenous Autonomy in the Americas
}

\author{
Alexandra Xanthaki
}

\subsection{Introduction}

The American continent has a long tradition of autonomous regimes, both territorial and non-territorial. Autonomous regimes of American indigenous communities in particular have not been the subject of intense discussion and comparison, partly because the task of discussing such autonomous regimes in the whole of the Americas represents a huge challenge. Although all American indigenous peoples have as a common denominator the European colonization and their subsequent extinction to a large degree, their stories certainly differ. 'Caught within colonial systems, whether through imperialism as settlers arrived in their territories or through the nation-state system and its hierarchy of categories designed to protect and promote the powerful', ${ }^{1}$ their situation has been shaped considerably by their specific history of colonization. In Latin America, the Spaniards tried to rule the already existing indigenous societies: the encomieda system allowed prominent Spaniards to be in charge of indigenous communities. In exchange for their labour and resources, the Spanish lord would guarantee protection and education. It was

\footnotetext{
${ }^{1}$ Mario Blaser, Ravi de Costa, Deborah McGregor, and William D. Coleman, 'Reconfiguring the Web of Life: Indigenous Peoples, Relationality, and Globalisation', in Indigenous Peoples and Autonomy, Insights for a Global Age, edited by Mario Blaser, Ravi de Costa, Deborah McGregor, and William D. Coleman (Vancouver: UCB Press, 2010), p. 17.
} 
'thinly masked slavery'. In North America, the English chose to create new societies separate from the existing indigenous communities. After wars, enslavement, and forced relocations, they often concluded treaties of coexistence, albeit at times with dire conditions for indigenous groups. ${ }^{2}$ The different strategies of colonizers were determined also by the circumstances, for example the large numbers of indigenous inhabitants in Latin America and the rather smaller numbers of indigenous inhabitants in North America. As time went by, the lines between Spaniards and indigenous Americans became blurred in Latin America, whereas such lines remained rather obvious in North America. At the same time, the Spaniards were more focused on taking the natural resources of the territories they occupied, whereas the English spent more time developing trade and agriculture. Nothwithstanding the different ways, both strategies led to the extinction, structural discrimination, and historical injustices of the American indigenous communities.

Indigenous peoples of the whole of the Americas suffered intensely from centuries of assimilation polices imposed on them by the newcomers. Panama and Brazil are notable examples of assimilation for centuries, but so are Guatemala and its adopted

\footnotetext{
${ }^{2}$ Christopher Minster, 'Spain's American Colonies and the Encomienda System', accessed 3 March 2015, http://latinamericanhistory.about.com/od/theconquestofperu/p/Spain-S-American-
} Colonies-And-The-Encomienda-System.htm. 
policies 'of 'containment, if not overt extermination', 3 Bolivia in the pre-Morales era, Canada and the US. ${ }^{4}$

Indigenous peoples in North America have seen an improvement in their rights, although their relationship to the states is defined 'by the historical exercise of hierarchical power by the state over Aboriginal peoples, the marginalization and suppression of Aboriginal cultures, and lack of imagination in relation to Aboriginal forms of governance - features central to the colonial project in Canada' ${ }^{5}$ The US has so called government-to-government relations with approximately 566 American Indian and Alaska Native tribes and villages. Native Hawaiians do not have the same status, although they have some form of federal recognition, whereas other indigenous groups are not federally recognized, even though some have acquired status at the state level. ${ }^{6}$

${ }^{3}$ Jonathan T. Hiskey and Gary L. Goodman, 'The Participation Paradox of Indigenous Autonomy in Mexico', Latin American Politics and Society, vol. 53, no 2 (2011): p. 62.

${ }^{4}$ For example see James Anaya, 'The Situation of Indigenous Peoples in the United States of America', UN Doc A/HRC/21/47/Add.1 (2012); Marc Chevrier, Canadian Federalism and the Autonomy of Quebec: A Historical Viewpoint (Quebec:

Gouvernement du Quebec, 1996); Michael Asch, On Being There to Stay, Treaties and Aboriginal Rights in Canada (Toronto: Toronto University Press, 2014).

${ }^{5}$ Michael Coyle, 'Negotiating Indigenous Peoples' Exit from Colonialism: The Case for an Integrative Approach', Canadian Journal of Law and Jurisprudence, vol. 27 (2014): p. 286.

${ }^{6}$ See Anaya, 'The Situation of Indigenous Peoples in the United States of America', p. 5. 
The federally recognized tribes have reservations or other lands set aside for them, over which they exercise powers of self-government.

In Canada, in 1996 the state recognized that indigenous peoples have 'an inherent right to self-government' under Section 35 of the (1982) Constitution $\mathrm{Act}^{7}$ and promised the negotiation of new institutions of indigenous self-government in education, health, social services, language, culture, religion, policing, property rights, and the administration and enforcement of indigenous laws. This went further than the conditional powers available to indigenous communities under the Indian Act. ${ }^{8}$ Still, 'power imbalance, cultural dominance, and the challenge of reimagining governmental relationships between Aboriginal peoples and the state continue to dominate Canada's political landscape and influence contemporary negotiations aimed at altering their relationship'. 9

In Latin America, currently large numbers of indigenous peoples are found mainly where pre-colonial civilizations prospered: very large numbers in Bolivia and Guatemala, a significant percentage in Peru and Ecuador, and some smaller groups in

${ }^{7}$ See 'The Government of Canada Recognizes the Inherent Right of Self-Government as an Existing Aboriginal Right under Section 35 of the Constitution Act, 1982', Aboriginal Affairs and Northern Development Canada, accessed 3 March 2015, http://www.aadncaandc.gc.ca.

${ }^{8}$ See Indian Act, RSC 1985, ch 1-5, ss 81-85.1, as mentioned in Coyle, 'Negotiating Indigenous Peoples' Exit from Colonialism'.

${ }^{9}$ Coyle, 'Negotiating Indigenous Peoples' Exit from Colonialism', p. 286. 
Belize, Honduras, and Mexico. ${ }^{10}$ The past two decades have witnessed a process of change in many Latin American states. In some countries indigenous peoples are still far from reaching effective political rights and autonomy, but in other countries they have achieved a lot. Hiskey and Goodman note: 'From the election of Evo Morales as president of Bolivia in 2006 to the ongoing Zapatista conflict in southern Mexico, the collective voice of indigenous peoples across the region has grown increasingly louder, albeit in different forms, as their respective political systems have continued to open up to them. ${ }^{11}$ Several Latin American states have recently acknowledged their multicultural and pluri-ethnic character. Within this framework, several states, including Colombia, Bolivia, and Panama, have established or renewed legal arrangements for indigenous territorial autonomy that allow indigenous peoples to govern themselves according to their own principles and beliefs and through their own social institutions and systems. These arrangements 'purport to institutionalize forms of what could be called official (constitutional) political and legal pluralism'. ${ }^{12}$ These are important steps away from the

${ }^{10}$ Ana Lucia Salinas de Dosch, 'Understanding Latin America Indigenous Movements: From Marginalisation to Self-Determination and Autonomy?', Paper delivered at 3rd International Seminar and Workshop on Latin American and Asian Studies (LASA III), Institute of Occidental Studies, Universiti Kebangsaan Malaysia, 17-18 October 2012.

${ }^{11}$ Hiskey and Goodman, 'The Participation Paradox of Indigenous Autonomy in Mexico', p. 62.

${ }^{12}$ Joris van de Sandt, 'Communal Resource Tenure and the Quest for Indigenous Autonomy on State Law and Ethnic Reorganisation in Two Colombian Resguardos', Journal of Legal Pluralism (2003): p. 125.vol no? 
statist legal and political model that marginalized and oppressed indigenous peoples. However, such developments have stayed to a large degree on paper and have not been fully implemented, as this would require a complete overhaul of the relations between indigenous peoples and non-indigenous peoples in Latin America. ${ }^{13}$ Van Cott argues that while indigenous peoples in North America seem to be struggling to get more extensive autonomy over their affairs, the struggle of indigenous peoples in Latin America seems to be the reconciling of the duality between having the right to be indigenous and having rights as full and equal citizens of the states. ${ }^{14}$

\subsection{Definitional Issues}

Indigenous autonomy as a term is used rather loosely in the literature to denote a number of concepts ranging from political representation to development of indigenous languages and identities to organized political resistance. ${ }^{15}$ For example, de Costa notes that 'the richness and complexity of indigenous peoples autonomy projects are visible in

\footnotetext{
${ }^{13}$ Sandt, 'Communal Resource Tenure'.

${ }^{14}$ Donna Lee Van Cott, 'Indigenous Struggles', Latin American Research Review, vol.
}

38, no. 2 (2003): p. 221; Donna Lee Van Cott, 'Building Inclusive Democracies:

Indigenous Peoples and Ethnic Minorities in Latin America', Democratization, vol. 12, no. 5 (2005): pp. $825-42$.

${ }^{15}$ For example, Erich Fox Tree, 'Global Linguistics, Mayan Languages, and the Cultivation of Autonomy', in Indigenous Peoples and Autonomy, Insights for a Global Age, edited by Mario Blaser, Ravi de Costa, Deborah McGregor, and William D. Coleman (Vancouver: UCB Press, 2010), p. 91: ‘Autonomy means that every mayan language is distrete,[discrete??] complete, and productive'. 
interpersonal relations, struggles at the community level, regional arrangements regarding resource development, and the symbolic meanings that others attach to Indigenous peoples struggles'. ${ }^{16}$

In North America claims for autonomy are seen through the lens of the term 'sovereignty' and this concept is often used in relation to autonomous regimes. Although the concept of sovereignty has been used by US tribes to assert their previous independence, Anghie has criticized it as a mainly Eurocentric concept, arisen in the process of delegitimizing the claims of 'nomadic colonial peoples' and legitimizing the grabbing of their territories. ${ }^{17}$ Young has favoured a hybridized 'principle of local selfdetermination enacted in the context of global governance structures' manifested as a decentralized democratic federalism patterned on Iroquois concepts of federalism. ${ }^{18}$

${ }^{16}$ Ravi de Costa, 'Afterword', in Indigenous Peoples and Autonomy, Insights for a Global Age, edited by Mario Blaser, Ravi de Costa, Deborah McGregor, and William D. Coleman (Vancouver: UCB Press, 2010), p. 241.

${ }^{17}$ Antony Anghie, Imperialism, Sovereignty and the Making of International Law (Cambridge: Cambridge University Press, 2007), p. 310-11; also Radhika Mongia, 'Historicizing State Sovereignty: Inequality and the Form of Equivalence', Comparative Studies in Society and History, vol. 49, no. 2 (2007): pp. 384-411.

${ }^{18}$ Iris Marion Young, 'Hybrid Democracy: Iroquois Federalism and the Postcolonial Project', in Political Theory and the Rights of Indigenous Peoples, edited by Duncan Ivison, Paul Patton, and Will Sanders (Cambridge: Cambridge University Press, 2000), p. 254. 
For the purposes of this chapter, it seems that the best guide to understand the various aspects of American autonomous regimes is the draft American Declaration on the Rights of Indigenous peoples (draft American Declaration). Its elaboration started in 2006. Negotiations were stalled in 2012 and started again in 2015, though without evidence of serious progress. Nevertheless, the text of the draft American Declaration, quite similar to the United Nations Declaration on the Rights of Indigenous Peoples (UNDRIP), but modified to reflect the particularities of the region and the region's indigenous claims, offers a real insight into the understandings and categories of autonomous regimes in the region.

Provisions related to autonomy are scattered in the current text of the draft Declaration. The main relevant provision is Article XX, an article not yet adopted by the American states. Currently it reads:

1. Indigenous peoples, [as one of the ways to exercise their] [in the exercise of] the right to self-determination [within the states], have the right to autonomy or [and] self-government with respect to inter alia, culture, language, spirituality, education, [information, means of communication,] health, housing, employment, social well-being, maintenance [of community security], [of jurisdictional functions in matters of territory,] family relations, economic activities, administration of land and resources, environment and [entry of non-members]; [and to determine with states the ways and means of financing \{the exercise of these rights these autonomous functions]. 
2. Indigenous peoples have the right to maintain and develop their own decision-making institutions.

The current draft provision is a detailed version of the corresponding Article 4 of UNDRIP, which recognizes that 'indigenous peoples, in exercising their right to selfdetermination, have the right to autonomy or self-government in matters relating to their internal and local affairs, as well as ways and means for financing their autonomous functions'.

Let us see in more detail the different types of autonomy in the Americas.

\subsection{Territorial Autonomy}

In addition to Article XX, the draft American Declaration currently acknowledges in Article VI that indigenous peoples have the right 'to their social, political, and economic organisation; [to their legal systems]; [and to administer their lands, territories and natural resources].' Although states have not yet agreed on the recognition of indigenous peoples' legal systems and administration of their lands, it seems that their right to social, political, and economic organization is agreed.

\subsubsection{Territorial Autonomy in North America}

The past policies of separation between indigenous and non-indigenous peoples have particularly favoured territorial autonomy in North America. Indigenous band governments in Canada have had authority over their reserves for a long time, set out by the Indian Act. However, the system had a lot of problems. In 1983, the Special Committee of the House of Commons on Indian Self-Government recommended that the federal government recognize indigenous bands as a distinct order of government within the Canadian federation and begin to negotiate self-government agreements with Indian 
bands. In 1996, the Royal Commission on Aboriginal Peoples also recommended that Aboriginal governments become recognized as the third level of government in Canada, in addition to the federal government and the provinces; however, the shift had moved on from constitutional recognition to negotiation between the state and the various indigenous communities. Despite a large number of such negotiations since the 1990s, only about twenty such agreements have been reached, most of them closely linked to land claims. More than eighty negotiations are still pending and the federal government recently concluded that the self-government negotiation process is 'not sustainable', ${ }^{19}$ while the Supreme Court of Canada has thus far declined invitations to declare that selfgovernance is a constitutionally protected Aboriginal right. Tired of waiting for the negotiations to bear fruit, some indigenous communities have now started to act unilaterally. In January 2014, the Nipissing First Nation adopted what is believed to be the first constitution for a First Nation in Ontario that replaces the Indian Act as the supreme law on the governance of the First Nation. The initiative has not yet been tested in court. ${ }^{20}$

Such autonomous arrangements are in most cases related to land claims. Indeed, in order to make autonomous regimes effective, a number of other rights must also be recognized, such as the indigenous rights to manage the environment and their lands (art

${ }^{19}$ Coyle, 'Negotiating Indigenous Peoples' Exit from Colonialism', pp. 286-7.

20 'Nipissing First Nation Passes First Ontario Aboriginal Constitution', CBCNEWS, 21 January 2014, accessed 5 March 2015, http://www.cbc.ca/news/canada/sudbury/nipissing-first-nation-passes-first-ontarioaboriginal-constitution-1.2505488. 
XVIII.2 of the draft American Declaration), indigenous rights to free, prior, and informed consent related to the environment of their lands (art XVIII.3), and rights to create their own protected areas of conservation on their lands. The Inter-American Court for Human Rights has also recognized the important link between indigenous autonomy and land rights. In Awas Tingi v. Nicaragua, Saramaka v. Suriname, and Sarayaku v. Ecuador, the Court used the right to property, as recognized in Article 21 of the American Convention on Human Rights (ACHR), as the basis to discuss violations to indigenous autonomy. ${ }^{21}$ Unfortunately, the above-mentioned provisions have not yet been agreed in the American Declaration, even though of course states have consented to similar provisions of UNDRIP. It should be noted that following the initial rejections of UNDRIP, both Canada and the US later agreed to its content. Indigenous autonomy cannot be disentangled from indigenous struggle for control over their territories. In Canada, when the Quebec government started hydroelectric projects after a period of intense forestry and mining development without Cree involvement, the Crees began to oppose such projects that harmed their lands. ${ }^{22}$ After resorting to the courts and rejecting a quick settlement, negotiations began with the federal government and Quebec that led to the

${ }^{21}$ Tom M. Antkowiak, 'Resources, and Rhetoric: Indigenous Peoples and the InterAmerican Court', University of Pennsylvania Journal of International Law, vol. 35, no.1 (2014): pp. 113-87.

${ }^{22}$ Harvey A. Feit, 'Neoliberal Governance and James Bay Cree Governance', in Indigenous Peoples and Autonomy, Insights for a Global Age, edited by Mario Blaser, Ravi de Costa, Deborah McGregor, and William D. Coleman (Vancouver: UCB Press, 2010), p. 60. 
James Bay and Northern Quebec Agreement (JBNQA), signed in $1975 .{ }^{23}$ The agreement allowed the project to continue but recognized the rights of the Crees to live their own way of life and established measures to ensure the Crees' land use and participation in decision-making. It established co-management in many areas of policymaking, but the state decisions would still be subject to the final authority of the state. Despite the agreement, Crees continued to be excluded from decision-making regarding the development of the land, their governance in the territory, and their participation in resource development and benefits. ${ }^{24}$

Currently, the Cree autonomous regime in Quebec is also not subject to the Indian Act. The Cree-Naskapi (of Quebec) Act of 1984 recognized that nine Cree communities are not subject to the Indian Act or the band system, but are represented by the Grand Council of the Crees (Eeyou Istchee) or GCCEI and governed by the Cree Regional Authority. The Grand Council of the Crees signed an agreement in 2012 with the province of Quebec that would abolish the municipalities in the region and merge them with the Cree Regional Authority in a new regional government called the Eeyou Istchee James Bay Territory. They are still in talks with the federal government on a Cree Nation Governance Agreement to refine the new structure's relationship to the federal authorities. Coyle has discussed the negative effects of asymmetries in negotiation power on negotiations relating to self-government between indigenous peoples and the state. ${ }^{25}$

\footnotetext{
${ }^{23}$ Feit, 'Neoliberal Governance and James Bay Cree Governance', p. 61.

${ }^{24}$ Feit, 'Neoliberal Governance and James Bay Cree Governance', p. 62.

${ }^{25}$ Michael Coyle, 'Transcending Colonialism? Power and the Resolution of Indigenous
}

Treaty Claims in Canada and New Zealand', NZULR, vol. 24 (2011): p. 596. 
In addition to the land element, two self-government agreements in Canada recognize indigenous autonomy over educational matters. In Nova Scotia and British Columbia, law-making authority has been conferred on the indigenous communities, with the government of Canada providing education programme and governance funding through a transfer agreement to the signatory groups. In Nova Scotia, an education selfgovernment agreement has been in place since 1997. As part of this agreement, the First Nations that operate on-reserve schools do so through the Mi'kmaw Kina'matnewey (MK) education organization. MK has a Master Education Agreement with the Nova Scotia Ministry of Education, which formalizes collaboration between the two organizations. In British Columbia, eleven First Nation bands have been given selfgovernment on education matters after agreements with the government and the province. The Agreement allows participating communities to 'provide primary, elementary, and secondary education programs and services comparable to those provided by other education systems in Canada, so as to permit the transfer of students between education systems without academic penalty. ${ }^{26}$

A notably wide autonomous regime was agreed following the Nunavut Agreement in Canada. A new federal territory, Nunavut, was created in 1999, separate from the North Territories, where other indigenous communities lived. Nunavut is not reserved exclusively for the Inuit. Any adult Canadian citizen who has been living in

26 'Education Partnership in Nova Scotia', Aboriginal Affairs and Northern Development Canada, 9 September 2011, accessed 5 March 2015, https://www.aadncaandc.gc.ca/eng/1312900494134/1312900618854. 
Nunavut for more than a year can vote in its elections. ${ }^{27[13]}$ However the strong Inuit majority is reflected in the governance of the territory.

In addition to the political strategies and lobbying for more self-government, Canadian indigenous peoples have also resorted to litigation, with mixed results. As Peach notes, 'whereas Canadian courts have, on occasion, provided Indigenous peoples with significant victories, in cases such as Haida Nation v British Columbia (Minister of Forests) and Taku River Tlingit First Nation v British Columbia (Project Assessment Director), the courts have also provided them with a number of painful defeats and have only rarely questioned the legitimacy of the fundamental legal underpinnings of colonialism. 28

Although indigenous territorial autonomy units in Canada and the US have many similar characteristics, unlike Canada, the US Supreme Court has recognized that Indian tribes are inherently sovereign nations with powers of self-government. However, first, only recognized nations have self-government powers. This leaves indigenous peoples in Alaska and Hawaii in a very vulnerable position. Secondly, even recognized tribes who enjoy self-government, had both their sovereignty and their original land rights and are now under the power of the US. ${ }^{29}$ Anaya notes: 'tribes are sovereign nations with certain inherent powers of self-government and original rights, but they are rendered, in words penned by the famous Supreme Court Justice John Marshall, “domestic dependent

\footnotetext{
${ }^{27} \mathrm{http}: / / \mathrm{www} . e l e c t i o n s . n u . c a / a p p s /$ authoring/dspPage.aspx?page=qualify.

${ }^{28}$ Ian Peach, 'The Power of a Single Feather: Meech Lake, Indigenous Resistance and the Evolution of Indigenous Politics in Canada', Review of Constitutional Studies, vol. 16, no. 1 (2011): p. 1.

${ }^{29}$ Anaya, 'The Situation of Indigenous Peoples in the United States of America', para 14.
} 
nations," subject to the overriding power of the federal Government' ${ }^{30}$ Many selfgovernment structures are connected to treaties that were signed between the US and the tribes. Although the treaty-making stopped in 1871, 'many of the historical treaties with tribes continue in force as part of federal law and to define United States-tribal relations ${ }^{31}$ The (1924) Indian Reorganization Act included provisions that protected Indian lands and provided for establishing reservation-based governments similar to local municipalities. However, it served as a way of gradual assimilation. Many Indian tribes today continue under the IRA regime of the Indian Self-Determination and Education Assistance Act of 1975, by which tribes are able to assume the planning and administration of federal programmes that are devised for their benefit. The UN Special Rapporteur has highlighted some of the problems of territorial autonomous regimes for reservation autonomies. US courts have consistently restricted the self-government of such units, to limit the powers of tribal decision-making bodies and judiciary. ${ }^{32}$

\subsubsection{Territorial autonomy in Latin America}

Territorial autonomy is not restricted by any means to North America. Although some Latin American states have not established autonomy for their indigenous populations, for example Argentina, other include such arrangements in their constitution. Article 2 of the Constitution of Mexico 'guarantees and protects the rights of indigenous peoples and communities to self-determination and consequently to autonomy'. The examples of

\footnotetext{
${ }^{30}$ Anaya, 'The Situation of Indigenous Peoples in the United States of America', para 15.

${ }^{31}$ Anaya, 'The Situation of Indigenous Peoples in the United States of America'.

${ }^{32}$ Anaya, 'The Situation of Indigenous Peoples in the United States of America', paras
} $50-5$. 
Oaxaca and the Chiapas autonomous regimes (and their failures to move effectively from promises to reality) offer important lessons. ${ }^{33}$ In addition, Article 260 of the Constitution of Venezuela states that 'the legitimate authorities of the native peoples shall have the power to apply, within their territorial competence levels of administration of justice', whereas the Constitution of Bolivia (2009) recognizes in Article 190 the indigenous 'jurisdictional functions and competency through their authorities'. Even in cases where constitutionally territorial autonomy is not that strong, in practice, many indigenous groups in Latin America enjoy forms of territorial autonomy.

In some cases, autonomy is used as a way to weaken the rights of indigenous communities. Peru has no autonomy regimes in general for its indigenous populations, but only for the indigenous peoples in isolation and initial contact in its territory to which it refers as 'autonomous peoples'. 'Reserves' have been created for these communities since the 1980s, but the 2006 Law 28736 was adopted to further strengthen the framework of 'indigenous reserves'. This law created a weaker system of protection for these communities because it permits extractive activities within these units when such activities are found to be of national interest and an environmental impact assessment (EIA) - rather than a human rights impact assessment — has been approved by the state. This is catastrophic for these communities. ${ }^{34}$

\footnotetext{
${ }^{33}$ Rodolfo Stavenhagen, 'Politics, Identity, and Mexico's Indigenous Rights Movement (review)', Human Rights Quarterly, vol. 33, no. 4 (2011): pp. 1169-76.

${ }^{34}$ Jorge Agurto, 'Peru', in The Indigenous World 2014, edited by Cæcilie Mikkelsen

(Copenhagen: IWGIA, 2014), pp. 164-5.
} 
On the other hand, Nicaragua's indigenous autonomy has been considered a model to be followed. ${ }^{35}$ Although Central and Pacific Coast indigenous communities lack recognition, ${ }^{36}$ indigenous communities on the Atlantic coast of Nicaragua enjoy both territorial and non-territorial autonomy. Both the North Atlantic Autonomous Region and the South Atlantic Autonomous Region are governed by regional councils, while their indigenous inhabitants also enjoy non-territorial 'cultural autonomy'. ${ }^{37}$ After the Miskitu rebellion against the Sandinistas, autonomy was used in the 1980s as the prize of an ethnically exclusive, pan-indigenous movement. Law 28 on an Autonomy Statute for the Regions of the Atlantic Coast of Nicaragua ('Autonomy Law') recognized the Spanishspeaking mestizos, who were of mixed indigenous and Spanish origin and usually came from the Pacific coast of Nicaragua, the indigenous Miskito, Sumo, and Rama as well as

35 Jose Maria Arraiza, 'Squaring Indigenous Circles: The Making of Nicaragua's Indigenous Communal Property Regime', International Journal on Minority and Group Rights, vol. 69, no. 19 (2012): p. 72, also quoting Mary Finley-Brook and Karl Offen, 'Bounding the Commons: Land Demarcation in Northeastern Nicaragua', Bulletin of Latin American Research, vol. 28, no. 3 (2009): p. 345.

${ }^{36}$ M. M. Idiaquez, 'Ethnic Communities of the Pacific and North-Central Nicaragua', Envio, no. 136 (1992), accessed 5 March 2015, www.envio.org.ni/articulo/2557. Also, Juliet Hooker, “"Beloved Enemies”: Race and Official Mestizo Nationalism in Nicaragua', Latin American Research Review, vol. 40, no. 3 (2005): pp. 38-9.

${ }^{37}$ Michael Tkacik, 'Characteristics of Forms of Autonomy', International Journal on Minority and Group Rights, vol. 15 (2008): p. 371. 
the Garifunas and the Creoles, who were native-born descendants of African slaves ${ }^{38}$ and established concrete rights for them, including to communal forms of property. The governments of the 1990s largely ignored the Autonomy law, while backing private natural resources exploitation projects in the Atlantic. After years of struggles, the constitution now guarantees rights of indigenous peoples to non-discrimination, free association, free expression, education in their mother tongue, and the right to administer their own affairs in conformity with traditions ${ }^{39}$ as well as the approval of regional councils for any concessions and exploitation projects of natural resources in the Atlantic coast. $^{40}$ Although the implementation of the Autonomy law remains under question, at least it put an end to the rhetoric of a monocultural Nicaragua and opened a dialogue on the relationship between national politics and indigenous identity. ${ }^{41}$ In 2001 , indigenous

${ }^{38}$ Law 28 on an Autonomy Statute for the Regions of the Atlantic Coast of Nicaragua, art 2; Baron L. Pineda, Shipwrecked Identities, Navigating Race in Nicaragua's Mosquito Coast (New Jersey: Rutgers University Press, 2006), pp. 53-65; William Grigsby, 'Caribbean Coast: Multilingual, Multicultural and . . . Finally Autonomous?', Envio, no. 266 (2003).

${ }^{39}$ Constitution of the Republic of Nicaragua 1987, art 89, s 2, as amended by the Law on a Partial Reform of the Political Constitution, Law No. 192, 1 February 1995, Law No. 330, 18 January 2002, and Law No. 527, 8 April 2005.

${ }^{40}$ Arraiza, ‘Squaring Indigenous Circles', p. 73.

${ }^{41}$ Eric Rodrigo Meringer, ‘Accommodating Mestizaje on Nicaragua’s Rio Coco, Miskitu Activism before the Sandinista's Revolution', AlterNative: An International Journal of Indigenous Peoples, vol. 10, no. 3 (2014): p. 204. 
autonomy resurfaced after a ruling by the Inter-American Court for Human Rights found that the Nicaraguan government had violated the rights to communal property of the Mayangna community of Awas Tingni. ${ }^{42}$ The Court held that Nicaragua had to adopt the necessary measures to create an effective mechanism for demarcation and titling of the indigenous communities' territory, in accordance with their customary law, values, customs, and mores. Today, Nicaragua is again under Sandinista rule and the international debate on autonomy and indigenous-state relations is still lively. ${ }^{43}$ Since 2001, the Inter-American Court for Human Rights has also held judgements where indigenous autonomy is linked to the right to property.

\subsection{Autonomy and Representation}

In certain contexts, particularly in South America, indigenous peoples who form majorities of the states seek to increase their collective autonomy through electoral politics. In the recent post-liberal governments in several Latin American states, including Bolivia, Venezuela, and Ecuador, new opportunities for indigenous political rights have arisen. In Bolivia, Evo Morales, an Ayamara leader, came to power with the support of the indigenous peoples. In Guatemala, indigenous leaders worked towards a unified pan-Mayan identity that runs through different linguistic and cultural communities.

\footnotetext{
${ }^{42}$ Awas Tingi v. Nicaragua, The Mayagna (Sumo) Awas Tingni Community v. Nicaragua, Inter-American Commission of Human Rights Series C No. 79 (31 August 2001).

${ }^{43}$ Meringer, 'Accommodating Mestizaje on Nicaragua's Rio Coco, Miskitu Activism before the Sandinista's Revolution', p. 204.
} 
An important issue that arises relates to the administrational units of autonomy for indigenous communities. Hernández-Díaz maintains that in Mexico, the construction of municipalities 'have been reserved by indigenous peoples as a space from which they can defend their right to be different and counter central government policies. In local spaces, free of political positions and ideological debates, indigenous peoples have maintained, recreated, or developed forms of government different from those localities considered to be of mixed race or non-indigenous. Communities, at different moments in history, have used this institution as a means to defend themselves from, resist, and challenge the politics of the state. ${ }^{44}$ The question whether the autonomous area coincides with the boundaries of an indigenous territorial unit, or is bigger to incude an autonomous municipal territorial unit that includes indigenous peoples is important for the rights of indigenous communities. In the second scenario, indigenous voices may get lost among other voices. In several places in Latin America, the indigenous party controlled 'alternative municipalities' incorporate indigenous political and cultural elements, though at times without recognition of indigenous autonomies as such. ${ }^{45}$ However, in

\footnotetext{
${ }^{44}$ Jorge Hernández-Díaz, 'The Construction of Post-Liberal Citizenships: Claims of Municipal Autonomy and Indigenous Demands in Mexico', Latin American Research Review, vol. 45 (2010): p. 138.

45 Jonas Wolff, 'The New Constitutions and the Transformation of Democracy in Bolivia and Ecuador', in New Constitutionalism in Latin America: Promises and Practices,
} edited by Detlef Nolte and Almut Schilling-Vacaflor (Farnham: Ashgate, 2012), pp. 183202. 
some cases, the institution of the municipality works quite well for indigenous communities.

Certainly, autonomy in Latin America is not only a top-down approach. A notable example of a more organic formulation is the ayllu system, the traditional form of a community in the Andes, defined as 'a territory of a community of kin and (. . .) a socioeconomic organisation unit of the Andean culture that is based on solidarity and reciprocity'. ${ }^{46}$ Ayllus are self-sustained groups that own a piece of land and have specific hierarchies and obligations to one another. Schilling-Vacaflor discusses how the ayllu structures have been maintained in some areas of the highlands and valleys of Bolivia until today, despite the top-down syndical campesino organizations that have existed since 1952. Today, in some areas the ayllu continue to be the main autonomous organization of indigenous nations, whereas in others they have been substituted by the syndical organizations. Representatives of the ayllus are sent to the National Council of Ayllus and Markas of Qullasuyu (CONAMAQ), founded in 1997 to restore autonomy of indigenous peoples, including their 'collective rights to land and natural resources, redefinition of administrative units and self-determination exercised through indigenous

\footnotetext{
${ }^{46}$ Marcelo Francesco Osco, ‘Ayllu: Decolonial Critical Thinking and (AN)other Autonomy', Indigenous Peoples and Autonomy, Insights for a Global Age, edited by Mario Blaser, Ravi de Costa, Deborah McGregor, and William D. Coleman (Vancouver:
} UCB Press, 2010), p. 30. 
autonomies and direct representation in state institutions, ${ }^{47}$ CONAMAQ has a clear political vision for the indigenous peoples, that is, the return to pre-colonial relations between communities and the state, the rejection of existing political parties and syndicates as a dilution of indigenous power and claims, and the direct representation in state institutions, similar to Zapatistas' claims in Mexico. The rejection of political parties and of syndicates has put them in conflict with their former political allies-MAS, the political movement led by Evo Morales. CONAMAQ opposed the tendency to extend indigenous rights also to the campesino populations (peasants) and disagreed with the incorporation of indigenous originario campesino autonomies established in the new constitution. This case highlights the difficulties that arise in the construction of specific autonomous areas where indigenous peoples live; and the tensions between indigenous peoples and other vulnerable parts of the population in their quest for effective political participation. Similar tensions exist between some of the indigenous ayllus in the highlands and the Confederación Sindical Única de Trabajadores Campesinos de Bolivia (CSUTSB), the most important indigenous-campesino organization in Bolivia with the most members, founded in 1979. CSUTSB uses a 'pan-indigenous face', but being rather close to the government, it seems to promote autonomy of municipalities with rights equal to indigenous autonomies. The dual identity of indigenous peoples as indigenous and as members of the campesino syndicates has created challenges, deriving from the state's insistence on treating indigenous peoples in a similar manner to other vulnerable

\footnotetext{
${ }^{47}$ Almut Schilling-Vacaflor, 'Indigenous Identities and Politico-Juridical Demands of CSUTCB and CONAMAQ in the Constitutional Change Process of Bolivia', T'inkazos,
} La Paz vol. 11 (2008): pp. 23-4. 
groups. The ratification of UNDRIP as state law in October 2007 is powerful ammunition for indigenous peoples in Bolivia, because it explicitly recognizes special rights to indigenous peoples because of historical injustices, level of distinctiveness, and historical continuity of these nations.

In addition to the tensions that arise at times in constructing indigenous autonomies in the Americas (and beyond), and states' attempts to treat indigenous claims for autonomy in similar ways to other such claims or other administrative divisions, this case also shows how indigenous identity in some Latin American indigenous individuals coexists with other powerful identities, for example the identity of the peasant, and how indigenous peoples have to manage these identities. In similar ways, their vision for indigenous autonomy is also shared with other visions in the political sphere, such as the socialist vision or the post-liberal agenda; again such visions have to be managed and are on occasions in conflict. Zapatistas in Mexico have been criticized for pursuing autonomy, when their struggle should join the voices for globalization, deregulation, and open markets. ${ }^{48}$ This parallel struggle for more indigenous rights and other visions is not that obvious in North America, where indigenous struggles have not so actively joined other struggles. To a large degree, this may be explained as a consequence of the policy of separation that was pursued by colonizers in North America, which may have prevented indigenous peoples from actively sharing political agendas with nonindigenous peoples.

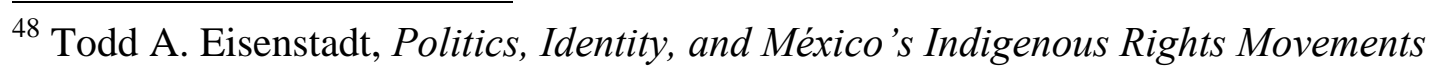
(Cambridge: Cambridge University Press, 2011); and the reply to the criticism in Stavenhagen, 'Politics, Identity, and Mexico's Indigenous Rights Movement (review)'. 
State interference in the way indigenous local governments are run is often justified on the basis of improving the system or ensuring democratic structures. However, in reality many of these structures weaken the indigenous political units and their representation. Oaxaca was the first state in Mexico to recognize in 1995 the practice of usos y costumbres, or customary law, as a legal means of selecting local leaders and managing day-to-day municipal operations. Since colonial times, 412 out of 570 municipios in Oaxaca have run their affairs locally by a form of usos y costumbres. Most of these municipios were indigenous communities and the usos y costumbres included traditional customs and customary law to elect their local leaders. Since being included in state law, usos y costumbres has competed with the open-list electoral political party regime that prevails in the rest of the municipios and in the rest of the state. The usos y costumbres system was not based on democratic structures, ballot was not secret and some communities have systematically excluded some sections of the population, such as women, from participation in local political affairs. So, in 1995, the state gave citizens living in usos municipalities the option of voting for whomever they wanted in state and national elections while being formally allowed to continue their use of non-partisan, customary selection methods for local government offices. This was envisaged as a positive reform. However, as Stavahagen argues, '[w]hatever its original purpose, making it legal gave the governing PRI party an edge over its political rivals in assuming ownership over these communities in the face of increasing hard-ball party politics in a democratizing Oaxaca, where left-wing political movements were on the rise. ${ }^{49}$ Hiskey and Goodman also criticize the initiative:

${ }^{49}$ Stavenhagen, 'Politics, Identity, and Mexico's Indigenous Rights Movement (review)', 
Without explicit efforts to strengthen indigenous citizens' ties to the national political community, however, the usos legislation effectively insulated these municipalities from the state's rapidly increasing multiparty electoral competition, increasing the chances that they would simply continue their clientelist relations with the PRI. This study argues that Oaxaca offers a textbook case of flawed and incomplete reforms producing consequences far beyond the immediate realm of the institutions in question. $^{50}$

\subsection{Non-Territorial Autonomy: Autonomy in Juridical Matters}

Non-territorial autonomous regimes in the Americas include a variety of arrangements. The provision of the draft American Declaration that recognizes the right of indigenous peoples 'to promote, develop and maintain their institutional structures and their distinctive customs, spirituality, traditions, procedures, practices and, in the cases where they exist, juridical systems or customs, in accordance with international human rights standards' has not yet been agreed. Article XXII-on the participation of indigenous peoples in decision-making in matters that affect them-is also controversial, 'including those that the state agrees to with other states and multilateral institutions, as well as in the process of development of legislative, administrative and juridical measures'.

p. 1173.

${ }^{50}$ Hiskey and Goodman, 'The Participation Paradox of Indigenous Autonomy in Mexico', pp. 64-6. 


\subsubsection{Free, prior, and informed consent as an expression of non- territorial autonomy}

There can be no discussion on indigenous autonomy in the Americas without touching on the requirement of free, prior, and informed consent of indigenous peoples (FPIC) on decisions that affect them. Today, this is a major concern of indigenous peoples all around the Americas. Having the autonomy to put a stop on big development projects is essential to their survival and prosperity. Rights to participation and consultation, seen as political rights, are included in several legislative texts of the Americas, but do not go far enough to protect indigenous peoples in situations of natural resources exploitation. In Bolivia, for example, the participation of indigenous peoples is promoted, and permits for energy production are judged on the basis of referendums at the municipal and departmental levels. However, there the voices of the indigenous communities, who are much more affected by such projects than other local populations, are continuously obscured by the majority views. ${ }^{51}$

FPIC is included in seven articles of UNDRIP, an instrument supported eventually by all American states. Article 19 of UNDRIP recognizes a collective right to giving or withholding consent by the indigenous peoples, according to the rules and procedures determined by the group itself, whereas Article 32(2) requires States to

\footnotetext{
${ }^{51}$ Secretariat of the Convention on Biological Diversity, 'Recognising and Supporting Territories and Areas Conserved by Indigenous Peoples and Local Communities, Global Overview and National Case Studies', CBD Technical Series, no. 64 (2012): p. 30, accessed on 2 March 2014, http://www.cbd.int/doc/publications/cbd-ts-64-en.pdf.
} 
'consult and cooperate in good faith with the indigenous peoples concerned through their own representative institutions in order to obtain their free and informed consent prior to the approval of any project affecting their lands or territories and other resources, particularly in connection with the development, utilization or exploitation of mineral, water or other resources. ${ }^{52}$ In 2009, the Human Rights Committee noted in Angela Poma Poma v. Peru, ${ }^{53}$ which involved the impact on water beneath indigenous peoples' lands, that 'participation in decision-making process must be effective, which requires not mere consultation but the free, prior and informed consent of the members of the community'. ${ }^{54}$ In the context of its Early Warning Urgent Action procedure the Committee on the Elimination of Racial Discrimination (CERD) has examined cases in Brazil, Canada, and Peru on their failure to obtain the FPIC of the affected indigenous peoples. ${ }^{55}$ The UN Committee on Economic, Social and Cultural Rights also affirmed in 2009 the duty of States 'to respect the principle of free, prior and informed consent of

$\overline{{ }^{52} \text { United Nations Declaration }}$ on the Rights of Indigenous Peoples (adopted 13 September 2007), art 32, s 2 (emphasis added).

${ }^{53}$ Human Rights Committee, ‘Ángela Poma Poma v. Peru' (adopted 24 April 2006) UN Doc. CCPR/C/95/D/1457/2006.

${ }^{54}$ Human Rights Committee, ‘Ángela Poma Poma v. Peru’, para 7.6.

${ }^{55}$ CERD, 'Summary Record of the First Part (Public) of the 1901st Meeting', 26

September 2008, UN Doc. CERD/C/SR.1901 (2008). 
indigenous peoples in all matters that affect them'. ${ }^{56}$ In its concluding observations to Colombia, the Committee repeated in 2010 that the right of indigenous peoples to FPIC should be respected before any project that affects indigenous peoples is implemented and that legislation must be enacted to ensure the respect of this indigenous right. ${ }^{57}$

How strong is the requirement for consent in development projects? The Mexican former Special Rapporteur on the Human Rights and Fundamental Freedoms of Indigenous Peoples, Rodolfo Stavenhagen, has referred to the 'right to free prior informed consent by indigenous peoples' which includes their 'right to say no' describing it as being of 'crucial concern' in relation to large-scale or major development projects and 'essential' for the protection of their human rights. ${ }^{58}$ His successor, James Anaya, has also adopted this line, explaining it further. Anaya has adopted a nuanced approach emphasizing that the strength of the requirement for FPIC would vary according to 'the

${ }^{56}$ Committee on Economic, Social and Cultural Rights (CESCR), 'General Comment No. 21 on the Right of Everyone to Take Part in Cultural Life' (adopted 21 December 2012) UN Doc. E/C.12/GC/21 (2009), paras 36-7.

57 'Concluding Observations on Colombia' (adopted 21 May 2010) UN Doc.

E/C.12/COL/CO/5 (2010); 'Concluding Observations on New Zealand' (adopted 30 May 2012) UN Doc. E/C.12/NZL/CO/3 (2012).

${ }^{58}$ CHR, 'Report of the Special Rapporteur on the Situation of Human Rights and Fundamental Freedoms of Indigenous People' (adopted 21 January 2003) UN Doc. E/CN.4/2003/90 (2003), paras 13 and 66. He points out that FPIC is necessary as too many major developments do not respect the consultation and participation criteria that are laid out in ILO Convention No. 169. 
circumstances and the indigenous interests involved ${ }^{59}$ He noted that a 'direct impact on indigenous peoples' lives or territories establishes a strong presumption that the proposed measure should not go forward without indigenous peoples' consent', and that 'in certain contexts, that presumption may harden into a prohibition of the measure or project in the absence of indigenous consent'. ${ }^{60}$ The Special Rapporteur has recognized the development of an international norm requiring the consent of indigenous peoples when their property rights are impacted by natural resource extraction. ${ }^{61} \mathrm{He}$ has confirmed that the

${ }^{59}$ Human Rights Council, 'Promotion and Protection of all Human Rights, Civil, Political, Economic, Social and Cultural Rights, Including the Right to Development, Report of the Special Rapporteur' (adopted 15 July 2009) UN Doc. A/HRC/12/34 (2009), para 47.

${ }^{60}$ Human Rights Council, ' Promotion and Protection of all Human Rights, Civil, Political, Economic, Social and Cultural Rights, Including the Right to Development, Report of the Special Rapporteur'.

${ }^{61}$ The Special Rapporteur qualified this requirement by adding that FPIC may not be essential for projects that do not have these potential impacts as long as this was in line with the requirements of arts 46 and 32(3) of UNDRIP. James S. Anaya, 'Indigenous Peoples' Participatory Rights in Relation to Decisions about Natural Resource Extraction', Arizona Journal of International and Comparative Law, vol. 22, no. 1 (2005): pp. 7- 8; Human Rights Council, 'Promotion and Protection of all Human Rights, Civil, Political, Economic, Social and Cultural Rights, Including the Right to Development' (adopted 11 August 2008) UN Doc. A/HRC/9/9/Add. 1. 
general rule [is] that extractive activities should not take place within the territories of indigenous peoples without their free, prior and informed consent. Indigenous peoples' territories include lands that are in some form titled or reserved to them by the State, lands that they traditionally own or possess under customary tenure (whether officially titled or not), or other areas that are of cultural or religious significance to them or in which they traditionally have access to resources that are important to their physical well-being or cultural practices. Indigenous consent may also be required when extractive activities otherwise affect indigenous peoples, depending upon the nature of and potential impacts of the activities on the exercise of their rights. In all instances of proposed extractive projects that might affect indigenous peoples, consultations with them should take place and consent should at least be sought, even if consent is not strictly required. ${ }^{62}$

The Inter-American System of Human Rights has been vocal on FPIC. The InterAmerican Commission on Human Rights has confirmed the need for consultation in cases of natural resource extraction since $2001 .^{63}$ In 2007, the Court held in Saramaka

${ }^{62}$ Human Rights Council, 'Report of the Special Rapporteur on the Rights of Indigenous Peoples, Extractive Industries and Indigenous Peoples' (adopted 1 July 2013) UN Doc. A/HRC/24/41 (2013), para 27.

${ }^{63}$ Marie and Carrie Dann v. United States Case 11.140 (Report 75/02 (2002), para 130) Inter-American Commission of Human Rights; Mayagna (Sumo) Awas Tingni 
People v. Suriname ${ }^{64}$ that in the case of large-scale development or an investment project that would have an impact on indigenous communities, the State 'has the duty, not only to consult with the [indigenous group], but to obtain their free, prior and informed consent, according to their customs and traditions ${ }^{9}{ }^{65}$ The Court was asked to decide on whether logging and mining concessions awarded by the State to third parties on indigenous lands violated indigenous rights and affirmed that in some cases the scope of Article 21 of the $\mathrm{ACHR}^{66}$ may comprise the exploitation of indigenous sub-soil resources. ${ }^{67}$ Unfortunately, the 2012 case of Kichwa v. Ecuador ${ }^{68}$ does not refer to the right to FPIC as such, but discusses instead the 'right to consultation with the aim of reaching an agreement or obtaining consent'. ${ }^{69}$ The Court held that 'the State did not conduct an appropriate and effective process that would guarantee the right to

Community v. Nicaragua (Merits, Reparations and Costs) Inter-American Court of Human Rights Series C No. 79, para 25 (31 August 2001).

${ }^{64}$ Saramaka People v. Suriname (Preliminary Objections, Merits, Reparations, and Costs) Inter-American Court of Human Rights Series C No. 172.

${ }^{65}$ Awas Tingi v. Nicaragua, The Mayagna (Sumo) Awas Tingni Community v. Nicaragua, para 134.

${ }^{66}$ ACHR, 'OAS Treaty Series No. 36’ (ACHR) (adopted 22 November 1969).

${ }^{67}$ Saramaka People v. Suriname, para 126.

${ }^{68}$ Pueblo Indigena Kichwa de Sarayaku v. Ecuador (Merits and Reparations) InterAmerican Court of Human Rights Series C No. 245 (27 June 2012).

${ }^{69}$ Human Rights Committee, Communication No. 1457/2006, Ángela Poma Poma v. Peru, para 185. 
consultation of the Sarayaku people before undertaking or authorizing the program of exploration or exploitation of resources on their territory' ${ }^{70}$

\subsubsection{Autonomy in judicial matters}

Contrary to FPIC, where there is a lot to be done to protect it in the Americas, indigenous autonomy in judicial matters is more accepted than in other parts of the world. The recognition of indigenous juridical systems (art 34 of UNDRIP) has been quite a controversial issue during the elaboration of UNDRIP; in contrast, Article XI of the draft American Declaration which recognizes 'the juridical personality of the indigenous peoples, respecting indigenous forms of organisation' has already been agreed by member states whereas American States approved in 2011 that 'the indigenous law and legal systems shall be recognised and respected by the national, regional and international legal systems'.

Several American Constitutions are vocal on indigenous jurisdiction, both territorial and non-territorial. The Constitution of Bolivia 2009 states in Article 190 that 'the nations and native indigenous rural peoples shall exercise their jurisdictional functions and competency through their authorities and shall apply their own principles, cultural values, norms and procedures'. However, limitations are set in the next paragraph: 'The rural native indigenous jurisdiction respects the right to life, the right to defence and other rights and guarantees established in the Constitution.' Article 149 of the Constitution of Peru also states that 'The authorities of the Native and Peasant Communities, with the support of the Peasant Rounds [Rondas Campesinas], may

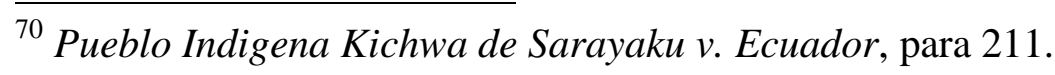


exercise jurisdictional functions within their territory in accordance with common law, provided that they do not violate the fundamental rights of the individual.'

More cautiously, Article 260 of the Constitution of Venezuela proclaims: 'The legitimate authorities of the native peoples shall have the power to apply, within their territorial competence levels of administration of justice based on their ancestral traditions and affecting their members only, in accordance with their own rules and proceedings, provided the same are not contrary to this Constitution, law and public order. The manner in which this special competence shall be co-ordinated with the national judicial system shall be determined by law.'

Article 246 of the Constitution of Colombia also sets domestic law as a limitation to indigenous jurisdiction: 'The authorities of the indigenous peoples may exercise their jurisdictional functions within their territorial jurisdiction in accordance to their own laws and procedures, provided that these are not contrary to the Constitution and to the laws of the Republic. The law will establish the forms of coordination of this special jurisdiction with the national judicial system.' The Constitution of Ecuador also explicitly recognizes in Article 1910 that indigenous authorities have judiciary functions in which they can apply customary norms and procedures 'so long as they do not contest the constitution and the laws. Finally, the Constitution of Mexico in Article 2.II:

guarantees and protects the rights of indigenous peoples and communities to II. Apply their own normative systems in the regulation and solution of their internal conflicts, subject to the general principles of this Constitution, respecting individual guarantees, human rights and, in relevant manner, the dignity and integrity of women. The law will 
establish the cases and procedures of validation by the corresponding judges or courts. $^{71}$

The Court held in Chavez that Article 2 does not create 'an independent and exclusive legal sphere only for indigenous communities. On the contrary, it is a statement that entails special care. ${ }^{, 72}$

It is interesting that some of these constitutions, for example Peru, do not require that indigenous jurisdiction is in conformity with all legislation, but specifically only with Constitutional guarantees. Making indigenous jurisdiction stand only when in conformity with domestic law defeats the point and sweeps away the essence of autonomy. Even the prevalence of the Constitution over indigenous jurisdiction seems questionable; the condition of having indigenous jurisdiction dependent on international human rights law seems adequate to ensure human rights and also to be in the spirit of indigenous real

${ }^{71}$ Constitución Política de los Estados Unidos Mexicanos 1917 [Political Constitution of the United Mexican States], art 2.

${ }^{72}$ Helga Maria Lell, 'The Concept of Citizenship: Multicultural Challenges and Latin American Constitutional Democracy', Birkbeck Law Review, vol. 87, no. 2 (2004): p. 110. For the case, see Juicio para la Protecci6n[please check ??] de los Derechos Politico Electorales del Ciudadano, Expediente SUP-JDC-1 1/2007, Tribunal Electoral del Poder Judicial de la Federacion (Distrito Federal) Joel Cruz Chavez y Otros. [The State v. Chavez and others (Trial to Protect the Political and Electoral Rights of Citizens) SUPJDC-1 1/2007 Mexican Electoral Tribunal of the Federal Judiciary]. 
autonomy and self-determination. ${ }^{73}$ Any such assessment about the indigenous cultural norm must allow for a certain deference to the group's 'own interpretive and decisionmaking processes in the application of universal human rights norms, just as states are accorded such deference' ${ }^{74}$ The Supreme Court of Colombia seems to lean towards such interpretation: the Court has held that limiting the community's autonomy, when it comes to situations regarding internal control, should be 'the minimum acceptable', and therefore 'can only relate to what is truly intolerable in that they endanger man's most precious assets. ${ }^{75}$ Gomez Isa elucidates that 'the Constitutional Court included in 'this core of untouchable rights only the right to life, the prohibition of slavery and the

${ }^{73}$ Alexandra Xanthaki, 'Normative Directions', in Indigenous Peoples' Access to Justice, edited by Wilthon Littlechild and Elsa Stamatopoulou (Place?: Institute for the Study of Human Rights, Columbia University, 2014), pp. 21-40; also Alexandra Xanthaki, 'Multiculturalism and International Law: Discussing Universal Standards', Human Rights Quarterly, no. 1 (2010): pp. 21-48.

${ }^{74}$ James Anaya, 'International Human Rights and Indigenous Peoples: The Move Towards the Multicultural State', Arizona Journal of International and Comparative Law, vol. 21, no. 1 (2004): p. 26.

${ }^{75}$ Corte Constitucional de Colombia (C.C.) (Colombian Constitutional Court), Sentencia T-349/96, 8 August 1996, II [do we need to retain this mark? NO]2.3 (Colom.) As translated and quoted in Gomez F. Isa, 'Cultural Diversity, Legal Pluralism, and Human Rights from an Indigenous Perspective: The Approach by the Colombian Constitutional Court and the Inter-American Court of Human Rights', Human Rights Quarterly, vol. 36, no. 4 (2014): p. 738. 
prohibition of torture ${ }^{, 76}$ as well as 'the legality of proceedings and, in criminal matters, the legality of offences and sentences' ${ }^{77}$ Very interestingly, the Constitutional Court held that 'only in relation to these can the existence of true intercultural consensus be predicated ${ }^{78}$ This of course limits a lot the leeway that the state has to restrict the rules deriving from indigenous autonomous regimes that relate to wholly internal indigenous situations, in cases when 'all the elements defining a particular situation involve an indigenous community: both the perpetrator of the conduct and the injured party belong to the community, and the events have taken place within the territory of that community ${ }^{79}$ Gomez Isa discusses some cases where the community itself revisited and revised its own cultural rules. For example, she mentions how the U'wa community revisited their cultural practice of rejecting babies with serious defects or as a result of multiple births. ${ }^{80}$

\footnotetext{
${ }^{76}$ Gomez, 'Cultural Diversity, Legal Pluralism, and Human Rights from an Indigenous Perspective'.

${ }^{77}$ Gomez, 'Cultural Diversity, Legal Pluralism, and Human Rights from an Indigenous Perspective'.

${ }^{78}$ Gomez, 'Cultural Diversity, Legal Pluralism, and Human Rights from an Indigenous Perspective'.

${ }^{79}$ Gomez, 'Cultural Diversity, Legal Pluralism, and Human Rights from an Indigenous Perspective', p. 738.

${ }^{80}$ Gomez, 'Cultural Diversity, Legal Pluralism, and Human Rights from an Indigenous Perspective', p. 742.
} 
Notable on this point is the recognition of the indigenous family norms and rules in the American draft Declaration, an important addition to provisions of UNDRIP. Agreed Article XVI recognizes 'the various indigenous forms of family, in particular the extended family, as well as the forms of matrimonial union, filiations, descent, and family name'. However, the current text also proclaims that states should 'take into account, primarily, the applicable indigenous law' in family matters and that 'the indigenous institutions, and indigenous courts where they exist' shall have jurisdiction (art XVI), an addition which has not yet been accepted by States.

Another interesting discussion that arises relates to the binding power of tribal laws in reservations on non-indigenous people. In the US, laws such as the Major Crimes Act of 1885 and Public Law 280 of 1953 have extended state criminal and civil jurisdiction in Indian country whether it relates to an indigenous or non-indigenous. The application of indigenous reservation laws to non-indigenous is a very important one as reports of a rape or sexual assault 'epidemic' among US indigenous women have recently surfaced. According to the US Department of Justice, 'in at least 86 per cent of the reported cases of rape or sexual assault against American Indian and Alaska Native women, survivors report that the perpetrators are non-Native men'; and many such assaults happen within reservations. ${ }^{81}$ Amnesty International notes that 'the complex interrelation between federal, state and tribal jurisdictions (. . .) undermines tribal

81 'Maze of Injustice, A Summary of Amnesty International's Findings', Amnesty

International, accessed 5 March 2015, http://www.amnestyusa.org/our-

work/issues/women-s-rights/violence-against-women/maze-of-injustice. 
authority and often allows perpetrators to evade justice'; ${ }^{82}$ and ultimately fails victims. The concern about strict indigenous norms and laws is balanced by the need that such norms follow international human rights standards.

\subsection{Conclusions}

Autonomous regimes in the Americas differ substantially, a legacy of different circumstances, different colonial strategies, and different evolution of the states in which they live. In Latin America, indigenous claims for autonomy have run parallel to other political visions. Accordingly, Latin American indigenous groups seem to be in constant interaction (support but also competition) with other vulnerable groups. North American indigenous peoples are more separate in their struggle, which at times limits their impact on non-indigenous support. Still, the main challenges for the autonomy of all indigenous peoples in the Americas are similar: their primary concern is the impact of transnational corporations in their lands and territories. Autonomy in matters that affect them in the form of FPIC of indigenous peoples in such decisions is essential to protect their survival. Autonomy to apply their norms and rules is also important to them, for their cultural, political, and social development but also as a token of states' respect of their identity and self-determination. Territorial autonomy has been a way in some states to promote indigenous control over their lives. However, transcribing such autonomous regimes from paper to reality has been a real challenge. New international instruments, regional and international human rights bodies, and the transnational indigenous movement work hard in highlighting such weaknesses and promoting further indigenous quests for real and effective autonomy.

$\overline{82}$ 'Maze of Injustice, A Summary of Amnesty International's Findings'. 